\title{
POWER OF SHARING SUMBER DAYA KELAUTAN REPUBLIK INDONESIA
}

\author{
Ria Tri Vinata \\ Fakultas Hukum Universitas Wijaya Kusuma Surabaya \\ Jl. Dukuh Kupang XX No.53, Dukuh Kupang, Dukuh Pakis, Surabaya \\ Email: riatrivinata@gmail.com
}

\begin{abstract}
Maritime and marine development targets are very realistic considering the position of Indonesia is geographically located and has a comparative advantage because it is very close to the world market. On the other hand, Indonesia is located in the tropics with thousands of islands have a wealth and maritime and marine resource potential is very large. Awareness of the protection and preservation of the marine environment began to grow among the countries participating in the Convention; especially regarding the exploitation of natural resources is carried out on a large scale in the marine environment. Especially for marine areas that are still in dispute, the power of sharing activity is the distribution of marine resources with the agreement Joint exploitation the original problem as a potential source of conflict, transformed and directed into a source of cooperation. Such cooperation generally includes the exploration, exploitation, and sharing of benefits derived from the exploitation of natural resources in the region for the parties.
\end{abstract}

Keywords: Power of Sharing, Joint Exploitation, Marine Resources.

\begin{abstract}
Abstrak
Sasaran pembangunan maritim dan kelautan sangat realistis mengingat posisi Indonesia secara geografis sangat strategis dan memiliki keunggulan komparatif karena sangat dekat dengan pasar dunia. Di sisi lain, Indonesia yang berada di daerah tropis dengan ribuan pulau memiliki kekayaan dan potensi sumberdaya maritim dan kelautan yang sangat besar. Kesadaran akan perlindungan dan pelestarian lingkungan laut mulai tumbuh di kalangan negara-negara peserta konvensi, terutama menyangkut eksploitasi sumber-sumber kekayaan alam yang dilakukan secara besarbesaran di lingkungan laut. Terutama untuk wilayah laut yang masih bersengketa, kegiatan power of sharing merupakan pembagian sumber daya kelautan dengan perjanjian Joint eksploitation maka masalah yang semula potensial sebagai sumber konflik, diubah dan diarahkan menjadi sumber kerjasama. Kerjasama tersebut pada umumnya meliputi eksplorasi, eksploitasi, dan pembagian keuntungan yang diperoleh dari eksploitasi sumber daya alam di kawasan tersebut bagi para pihak.
\end{abstract}

Kata kunci : Power of Sharing, Joint Exploitation, Sumber Daya Laut.

\section{A. Pendahuluan}

Secara global laut meliputi dua pertiga dari seluruh permukaan bumi dan menyediakan sekitar 97\% dari keseluruhan ruang kehidupan di bumi dan laut telah membentuk dan mendukung keberadaan serta kehidupan umat manusia sejak munculnya mahluk hidup 
pertama dari laut. ${ }^{1}$ Sementara itu perairan laut merupakan tempat kehidupan ba gi beraneka ragam dan berjuta-juta makhluk hidup atau organisme, mulai dari yang tak terlihat mata atau microscopic seperti bakteri, sampai makhluk hidup terbesar di dunia. ${ }^{2}$

Wilayah laut mempunyai kegunaan dan manfaat yang sangat besar bagi hidup dan kehidupan masyarakat. Tingginya keanekaragaman hayati dilaut dapat merefleksikan potensi ekonomi perairan pesisir dan lautan tersebut. Nilai hakiki dari sumber daya alam, yaitu sebagai kekayaan atau aset ekonomi bagi generasi sekarang maupun generasi yang akan datang. Sumber daya hayati pesisir dan lautan memiliki peluang sangat besar untuk mengalami kepunahan spesies. Yang terutama disebabkan karena sumber daya hayati laut bias bersifat milik bersama atau common property atau siapa saja dan kapan saja boleh memanfaatkan. ${ }^{3}$ Kondisi ini akan mendorong orang memanfaatkan sumber daya tersebut semaksimal mungkin, tanpa batas tanggung jawab semestinya.

Pemanfaatan sumber daya alam yang terletak di bawah dan di sekitar garis batas wilayah laut, atau yang disebut juga sumber daya alam yang lintas batas transboundary natural resources. Secara tegas digolongkan sebagai sumber daya alam yang lintas batas yang terdapat dari dasar laut atau di bawah dasar laut yang meluas dari garis batas pada kedua sisi dari landas kontinen, sehingga sumber daya alam dari landas kontinen pihak yang satu baik seluruhnya ataupun sebagian, dapat dieksploitasi dari landas kontinen pihak yang lain. ${ }^{4}$

Demikian pula di kawasan wilayah laut yang garis batasnya masih merupakan persengketaan, bahkan tidak jarang persengketaan tentang garis batas wilayah laut itu muncul, disebabkan oleh masalah eksploitasi sumber daya alamnya. ${ }^{5}$ Di kawasan yang belum ada atau belum berhasil dicapai kata sepakat tentang garis batas wilayah laut atau saling tumpang tindih. Pada umumnya daerah perbatasan memiliki kandungan sumber daya alam yang potensial untuk dikembangkan dalam rangka memperkuat ketahanan masyarakat serta merupakan modal dasar dan peluang untuk percepatan pembangunan daerah masing-masing. ${ }^{6}$

Prager, EJ and SA Earle, The Ocean, McGraw-Hill, Monteral, 2000, hlm. 224

Nybakken, J.W., Biologi Laut: Suatu Pendekatan Ekologi, (Penerjemah: M Eidmen, Koebiono, Dietrich, Hutomo, dan Sukardjo).,PT Gramedia , Jakarta, 1986, hm. 335

3 Mubarak Djamali, OK Sumadiharga, Sumber Daya Rumput Laut dalam Potensi dan Penyebaran Sumber Daya Ikan Laut Di Perairan Indonesia, Komisi Nasional Pengkajian Stock Sumber Daya Ikan Laut Lembaga Ilmu Pengetahuan Indonesia. Dirjen Perikanan, LIPI, Puslitbangkan, Lapan, BPPT dan Fakultas Perikanan IPB, 1998,

4 lstilah lain untuk sumber daya alam yang lintas batas semacam ini adalah sumber daya alam yang merupakan suatu kesatuan atau unity of deposit atau unity of natural resources. 1stilah sumber daya alam yang lintas batas tampaknya hanya tepat untuk digunakan untuk menunjuk sumber daya alam dalam kawasan landas kontinen yang garis batas landas kontinennya sudah berhasil disepakati, sedangkan untuk sumber daya alam yang ada pada landas kontinen yang garis batasnya belum atau tidak berhasil disepakati, tentulah istilah sumber daya alam yang lintas batas ini kurang tepat, sebab garis batas landas kontinennya itu sendiri belum atau tidak ada. Sedangkan istilah sumber daya alam yang merupakan suatu kesatuan dapat digunakan untuk kedua-duanya.

5 Harry G Johnson, The New International Economic Order, Selected Papers No. 49 di unduh di https://www.chicagobooth.edu/ /media/0ABF9E91CCDB42C4BBA92737DCE91EEA.pdf

6 Marsetio, Aktualisasi Peran Pengawasan Wilayah Laut Dalam Mendukung Pembangunan Indonesia sebagai Negara Maritim Yang Tangguh. Makalah Laksamana TNI Dr. Marsetio, pada acara Kuliah Umum di hadapan Civitas Akademika Universitas Sumatera Utara di Medan, Januari 2015 
Di era globalisasi yang bercirikan liberalisasi perdagangan dan persaingan antar bangsa yang makin sengit, segenap sektor ekonomi harus mampu menghasilkan barang dan jasa yang berdaya saing tinggi. ${ }^{7}$ Sebagai negara bahari dan kepulauan terbesar di dunia, Indonesia memiliki potensi ekonomi kelautan yang besar dan beragam. Pembangunan ekonomi nasional yang terus berkembang akan makin bergantung pada potensi ekonomi kelautan. Negara harus mampu mendayagunakan potensi ekonomi dan sumberdaya pesisir dan lautan secara optimal dengan memperhatikan aspek kelestarian dan keberlanjutan lingkungan. ${ }^{8}$

Berdasarkan hal tersebut, konvensi menentukan bahwa setiap negara mempunyai kewajiban untuk melindungi dan melestarikan lingkungan laut. Di samping itu, konvensi juga menentukan bahwa setiap negara mempunyai hak berdaulat untuk memanfaatkan sumbersumber kekayaan alamnya sesuai dengan kewajibannya untuk melindungi dan melestarikan lingkungan laut. Mendasarkan pada latar belakang diatas maka perumusan masalah yang akan di teliti penulis adalah sebagai berikut: Konsep Power of Sharing Pemanfaatan Sumber Daya Alam Wilayah laut Republik Indonesia

\section{B. Pembahasan}

Salah satu unsur keberhasilan pembangunan adalah mengelola sumber daya yang tersedia untuk dimanfaatkan seoptimal mungkin. Walaupun tersedia banyak sumber daya, apabila tidak mampu dikelola apalagi tidak dikelola dengan baik maka kemajuan negara yang bersangkutan akan terhambat. Dalam sebuah negara, yang dominan mengelola snmber daya baik alam maupun manusia adalah negara.

Kekayaan dan potensi tersebut dapat dijadikan sumber bagi peningkatan kesejahteraan masyarakat. Salah satu hal mendasar yang menyebabkan belum optimalnya pemanfaatan sumberdaya maritim dan kelautan yaitu kurang memadainya sarana dan prasarana pendukung. Sektor maritim dan kelautan Indonesia diperkirakan dapat menjadi tumpuan pembangunan nasional yang berkelanjutan dan berkeadilan. Pertumbuhan ekonomi yang tinggi dapat dicapai apabila paradigma pembangunan nasional berubah dari yang selama ini eksploitasi di daratan ke pengembangan potensi ekonomi maritim dan kelautan.

Pembagian laut ${ }^{9}$ sesungguhnya sudah terjadi sejak abad ke-15 saat terjadi kesepakatan antara Portugis dan Spanyol yang dengan kekuasaannya membagi-bagi laut di dunia. Keduanya adalah kekuatan besar masa itu yang sangat berpengaruh. Di abad 20, usaha untuk menguasai laut ini terus berlanjut. ${ }^{10}$

Ibid.

8 Doug Bandow, The Law of the Sea Treaty Impeding American Entrepreneurship and Investment, Advancing Liberty From the Economy to Ecology, Competitive Enterprise Institute. 2007, hlm. 4

9 Penguasaan terhadap wilayah darat saja tidak cukup bagi suatu bangsa. Munculah kemudian usaha untuk menguasai laut di sekitar daratannya.

10 Melalui Ordonansi 1939, misalnya, Belanda yang menguasai Indonesia saat itu menetapkan bahwa kewenangan terhadap laut berjarak 3 mil laut dari garis pantai masing-masing pulau di Indonesia. Kawasan laut ini disebut laut teritorial atau laut wilayah yang juga diklaim oleh negara-negara lain ketika itu. Butcher, JG. 2009. Becoming and archipelagic state: the Djuanda Declaration of 1957 and the 'struggle' to gain international recognition of the archipelagic principle, in Cribb, R. and Ford, M. 2009 Indonesia beyond the 
Pada tahun 1945 Amerika melakukan langkah yang lebih agresif lagi, Presiden Harry S. Truman memproklamasikan bahwa dasar laut di sekitar daratan Amerika adalah kekuasaan Amerika sehingga mereka berhak memanfaatkan sumberdaya yang ada padanya. Pernyataan ini dikenal dengan Proklamasi Truman yang kemudian diikuti juga oleh negara-negara lain di Amerika Latin. Pada tahun 1957, Indonesia mendeklarasikan penguasaannya atas laut diantara pulau-pulau di Indonesia melalui Deklarasi Djuanda. ${ }^{11}$

Melihat fenomena klaim kawasan laut yang bersifat sporadis ini, pada tahun 1958 PBB merasa perlu adanya pengaturan penguasaan atas laut. Dilakukanlah Konferensi PBB pertama tentang United Nations Conference on the Law of the Sea yang menghasilkan Konvensi PBB tentang United Nations Conference on the Law of the Sea $1958 .^{12}$ Dalam perkembangannya, terjadi penyempurnaan hingga disepakti konvensi terbaru yaitu United Nations Conference on the Law of the Sea 1982 yang kini sudah diakui (diratifikasi) oleh 159 negera dan satu Uni Eropa. ${ }^{13}$

Kesadaran akan perlindungan dan pelestarian lingkungan laut mulai tumbuh di kalangan negara-negara peserta konvensi, terutama menyangkut eksploitasi sumber-sumber kekayaan alam yang dilakukan secara besar-besaran di lingkungan laut, serta penanggulangan dan pencegahan terhadap pencemaran perairan yang terjadi karena kecelakaan kapal-kapal, termasuk pembuangan limbah ke perairan.

Pembagian rejim Zona Ekonomi Eksklusif dan rezim Landas kontinental memacu redistribusi global akan sumber daya laut, karena selama ini akses dan kontrol masih menjadi wewenang negara pantai. The Law of the Sea Convention tidak memberi kriteria spesifik untuk berbagi sumber daya, praktiknya hak negara pantai dapat dideskripsikan sebagai hak untuk mengelola sumber daya hayati. Ini relatif masih benar sepanjang sumber daya terletak di dalam wilayah hukum satu negara. Namun, sumber daya terbagi dengan negara lain, atau berada diantara batas-batas perairan internasional, hal ini menjadi lebih rumit. ${ }^{14}$

Pembagian hak sumber daya kelautan bagi Indonesia, berbagai permasalahan batas laut yang belum selesai dengan negara tetangga, kerjasama hanya di lingkup keamanan batas laut, dan perjanjian pertukaran tawanan nelayan antar negara, kesemuanya belum merefleksikan aturan penggunaan bersama wilayah laut internasional di perbatasan, termasuk pemanfaatan sumber daya hayati di dalamnya. ${ }^{15}$ Indonesia selalu dirugikan atas pembagian sumber daya

water's edge- Managing an archipelagic state, Indonesian Update Series, RSPAS Australian National University, ISEAS, Singapore, hlm. 28-48

11 Hal ini merupakan respon atas Ordonansi 1939 yang dianggap tidak menguntungkan bagi Indonesia yang berbentuk kepulauan. Dengan hanya memiliki 3 mil laut dari masing-masing pulau, ada banyak laut bebas di antara pulau-pulau di Indonesia. Selanjutnya hal ini diperjuangkan di forum internasional.

12 I Made Andi Arsana, A Historical Survey of Indonesia's Maritime Boundary Agreements, Symposium on Maritime Boundaries in the Timor Sea: Perspectives in International Law Melbourne, 15 February 2016 di unduh di www.ugm.ac.id

13 Ibid

14 Hoel, Op. Cit

15 J. A. Draper, 1977, "The Indonesian Archipelagic State Doctrine and Law of the Sea: Territorial Grab or justifiable Necessity?”, International lawyer, Vol. 11, No. 1, hlm. 144 
laut yang ada di wilayahnya sendiri seperti illegal, unreported and unregulated fishing, ${ }^{16}$ yang hasilnya dibawa dan dimanfaatkan penuh oleh negara asing, pencurian biota laut semacam terumbu karang, bahkan kerjasama riset dengan negara lain. ${ }^{17}$

Pembagian hak sumber daya kelautan Indonesia dengan negara lain di wilayah perbatasan baru dapat dilakukan Indonesia jika penentuan batas-batas teritorial kelautan antar negara telah diselesaikan, iptek pengelolan sumber daya hayati laut telah teroptimalkan, serta kelembagaan manajemen kelautan telah terintegrasi dan terkoordinasi kuat. Dalam pengelolaan laut ZEE perlu mendapat dukungan, agar ekonomi maritim kedepan bisa terkelola optimal. ${ }^{18}$ Jika kelautan sudah di tata kelola dengan baik, ${ }^{19}$ maka pemanfaatan sumber daya hayati laut dapat dibagi sesuai dengan kriteria pengelolaan yang telah dilakukan masing-masing negara atau bagi hasil sesuai dengan nota kesepakatan sebelumnya atau bahkan melalui konsensus politik dengan negara lain. ${ }^{20}$

Salah satu aspek hukum yang perlu mendapat perhatian dari Pemerintah Republik Indonesia adalah ketentuan Article 62 dari UNCLOS 1982 yang berisikan ketentuan kewajiban negara pantai untuk memberikan kesempatan kepada negara lain dalam pemanfaatkan sumber daya hayati perikanan di perairan ZEE, dalam hal negara pantai tidak mampu mengeksploitasi secara penuh sumber daya perikanan di perairan yuridiksi ZEE-nya.

Sebagai negara yang telah memperjuangkan aspek legal status wilayah nasionalnya sebagai Negara Kepulauan sejak Deklarasi Djuanda tahun 1957, sampai dengan saat ini perkembangan yuridis sebagai dasar diberdayakannya potensi kemaritiman ${ }^{21}$ dan kelautan Indonesia terus berjalan dan mengalami perkembangan yang cukup pesat seiring dengan

16 Laporan Penelitian dan Jurnal Araf, Al 2011, “Konsepsi dan Operasionalisasi Keamanan Nasional”, Jurnal Pertahanan. Universitas Pertahanan Indonesia, Edisi 1. 87-96. Jakarta.

17 Sihotang, Japanton, Masalah Perbatasan Wilayah Laut Indonesia di Laut Arafura dan Laut Timor. LIPI Press., Jakarta, 2009

18 Astim Riyanto, Negara Kesatuan: Konsep dan Aktualisasinya, Yapemdo, Bandung, 2006,

19 Dirjen Strahan, 2007, Kajian Optimalisasi Penanganan Wilayah Perbatasan Maritim RI-RDTL Dalam Rangka Menjaga Keutuhan NKRI. Jakarta: Departemen Pertahanan RI., hlm. 28

20 John Crawfurd, A Descriptive Dictionary of the Indian Islands and Adjacent Countries, Oxford University Press, Kuala Lumpur, 1971, hlm. 13-14.

21 Upaya membangun Indonesia sebagai sebuah negara maritim yang kuat dan tangguh sehingga dapat menjadikan Indonesia sebagai Poros Maritim Dunia harus dilaksanakan dalam konteks Indonesia sebagai negara hukum (rechtstaat) sebagaimana diamanahkan dalam UUD 1945. Hal ini berarti bahwa upaya ke arah pembangunan Negara Maritim harus didukung dan didasarkan pada peraturan-peraturan hukum yang memberikan legitimasi yang kuat kepada semua pemangku kepentingan dalam menjalankan perannya masingmasing. Pembukaan UUD 1945 pada Alinea ke-4 tegas menyebutkan bahwa tujuan Negara Kesatuan Republik Indonesia didirikan adalah: (1) melindungi segenap bangsa Indonesia dan seluruh tumpah darah Indonesia, (2) memajukan kesejahteraan umum, (3) mencerdaskan kehidupan bangsa, dan (4) ikut melaksanakan perdamaian dunia berdasarkan kemerdekaan, perdamaian abadi dan keadilan. Pasal 25A Undang-undang Dasar 1945 amandemen ke-IV, menyatakan bahwa "Negara Kesatuan Republik Indonesia adalah sebuah Negara Kepulauan yang berciri Nusantara dengan wilayah dan batas-batas dan hak-haknya ditetapkan dengan undang-undang”. Dengan demikian, kedudukan Indonesia sebagai Negara Maritim harus digunakan sebagai modal kekayaan pemberian Tuhan Yang Maha Kuasa untuk tujuan sebagaimana diamanahkan oleh Alinea ke-4 dari Pembukaan UUD 1945. Dengan kata lain pembangunan kemaritiman sekurangkurangnya memenuhi 4 (empat) tujuan yakni: tujuan pertahanan keamanan; kesejahteraan umum; edukasi; dan tujuan perdamaian internasional. 
proses dinamika kebangsaan dan dipengaruhi oleh perkembangan lingkungan strategis baik regional maupun global. ${ }^{22}$

Pemanfaatan kekayaan alam yang berada di wilayah perairan laut Indonesia secara eksploitatif memang dapat memberikan peningkatan pendapatan masyarakat, namun dapat merusak lingkungan. ${ }^{23}$ Pencemaran lingkungan pesisir dan laut dapat diakibatkan oleh beberapa faktor seperti limbah buangan kegiatan di daratan maupun di lautan. Aktivitas ekonomi di daratan yang berpotensi merusak dan mencemari lingkungan pesisir dan laut, antara lain penebangan hutan, pembuangan limbah industri, limbah pertanian, limbah cair domestik dan limbah padat, konversi lahan mangrove dan lamun, serta reklamasi di kawasan pesisir.

Sementara itu, aktivitas di laut yang berpotensi mencemari lingkungan pesisir dan laut, antara lain perkapalan, pembuangan sampah di laut, pertambangan, eksplorasi dan eksploitasi minyak, budidaya laut, dan perikanan. Indonesia memiliki potensi untuk menjadi negara kuat karena merupakan negara besar, baik dari jumlah penduduk maupun luas wilayahnya. ${ }^{24}$

Adanya perjanjian-perjanjian tentang garis batas landas kontinen, putusan-putusan badan penyelesaian sengketa tentang garis batas landas kontinen, ataupun kegagalan para pihak dalam mencapai kata sepakat tentang garis batas landas kontinen, ternyata masih meninggalkan satu masalah yang tidak kalah penting. ${ }^{25}$

Apabila eksploitasi secara sendiri-sendiri oleh masing-masing pihak, besar kemungkinannya akan timbul persengketaan. Dalam praktek negara-negara, sumber sengketa semacam ini diarahkan untuk dijadikan sebagai obyek kerjasama, dengan mengadakan perjanjian tentang joint exploitation atau joint development. Dalam hal yang pertama, perjanjian itu merupakan kelanjutan dari perjanjian tentang garis batas landas kontinen, sedangkan dalam hal yang kedua, perjanjian itu merupakan alternatif dari kegagalan para pihak untuk membuat perjanjian tentang garis batas landas kontinen. Dalam doktrin,

22 Konsep kemaritiman dan kelautan merupakan konsep yang multidimensi, yang meliputi dimensi pertahanan keamanan, dimensi ekonomi dan lingkungan, dan dimensi sosial budaya. Begitu juga lingkup hukum yang mengaturnya tidak saja meliputi hukum nasional, tetapi acapkali bersentuhan dengan hukum internasional dengan perubahan dan percepatan substansi regulasi yang demikian cepat. Oleh karena itu, landasan hukum dalam pengembangan hukum dan kebijakan kemaritiman dan kelautan harus dapat bergerak seiring dengan percepatan perubahan peta regulasi global sedemikian sekaligus dapat menjawab kebutuhan regul asi di tingkat nasional dan daerah. Diundangkannya Undang-Undang Nomor 32 Tahun 2014 tentang Kelautan yang merevisi beberapa ketentuan yang terdapat dalam Undang-Undang Nomor 6 Tahun 1996 tentang Perairan Indonesia setidaknya penyelenggaraan kelautan Indonesia diarahkan pada aspek: Wilayah laut; Pembangunan kelautan; Pengelolaan kelautan; Pengembangan Kelautan; Pengelolaan Ruang dan perlindungan laut; Pertahanan, keamanan, penegakan hukum dan keselamatan di laut serta tata kelola kelembagaan.

23 Adiyanto, E., E. Eidman, L. Adrianto, "Tinjauan Hukum Dan Kebijakan Pengelolaan Pulau-Pulau Kecil Terluar Indonesia (Studi Kasus Pulau Nipa)", Buletin Ekonomi Perikanan, Volume VII No. 2 Tahun 2007.

24 Darsono, P., "Pemanfaatan Sumber Daya Laut dan Implikasinya Bagi Masyarakat Nelayan”, Jurnal Oseana. Vol. XXIV No. 4, 1999. Hlm. 1 - 9.

25 Law of the Sea Bulletin No 23 June 1998 Division For Ocean Affair And The Law Of The Sea Office Of Legal Affairs, hlm. 67 
kepustakaan, ataupun praktek negara-negara, perjanjian semacam ini disebut joint exploitation agreement atau juga disebut joint development agreement. ${ }^{26}$

Melalui perjanjian ini, sumber daya alam yang menjadi obyek kerjasama di kawasan garis batas landas kontinen atau di kawasan landas kontinen yang tumpang tindih, secara hukum dijadikan sebagai satu kesatuan atau unity of deposit untuk selanjutnya dieksploitasi bersama sesuai dengan atau berdasarkan pada ketentuan-ketentuan perjanjian yang telah mereka sepakati. Secara umum, perjanjian semacam ini tidak terbatas hanya pada garis batas landas kontinen ataupun pada landas kontinen yang tumpang tindih saja, tetapi juga dapat dibuat dan diterapkan pada garis batas zona maritim lainnya seperti pada garis batas laut teritorial, dan garis batas zona ekonomi eksklusif. Bahkan juga dapat dibuat dan diterapkan untuk garis batas wilayah daratan. Masing-masing sesuai dengan obyek yang ada atau lintas batas pada garis batas dari zona maritim tersebut ataupun situasi dan kondisi setempat.

Melalui perjanjian ini, maka masalah yang semula potensial sebagai sumber konflik, diubah dan diarahkan menjadi sumber kerjasama. Kerjasama tersebut pada umumnya meliputi eksplorasi, eksploitasi, dan pembagian keuntungan yang diperoleh dari eksploitasi sumber daya alam di kawasan tersebut bagi para pihak.

Adanya perjanjian-perjanjian tentang garis batas landas kontinen, putusan-putusan badan penyelesaian sengketa tentang garis batas landas kontinen, ataupun kegagalan para pihak dalam mencapai kata sepakat tentang garis batas landas kontinen, ternyata masih meninggalkan satu masalah yang tidak kalah penting. ${ }^{27}$

Apabila eksploitasi secara sendiri-sendiri oleh masing-masing pihak, besar kemungkinannya akan timbul persengketaan. Dalam praktek negara-negara, sumber sengketa semacam ini diarahkan untuk dijadikan sebagai obyek kerjasama, dengan mengadakan perjanjian tentang joint exploitation atau joint development. Dalam hal yang pertama, perjanjian itu merupakan kelanjutan dari perjanjian tentang garis batas landas kontinen, sedangkan dalam hal yang kedua, perjanjian itu merupakan alternatif dari kegagalan para pihak untuk membuat perjanjian tentang garis batas landas kontinen. Dalam doktrin,

26 Istilah joint exploitation ataupun joint development ini ada yang digunakan secara tegas dalam sperjanjian yang bersangkutan, ada pula perjanjian yang tidak secara tegas menggunakannya. Perjanjian atau persetujuan yang menggunakan istilah joint exploitation, misalnya, Perjanjian antara Sudan dan Saudi Arabia yaitu Agreement between Sudan and Saudi Arabia relating to the Joint Exploration and Exploitation of the Natural Reseources of the Seabed and Subsoil of the Red Sea in a Defined Area of the Two Countries in the Red Sea, May. Persetujuan yang menggunakan istilah joint development, misalnya, Persetujuan antara Jepang dan Korea yaitu Agreement between Japan and the Republic of Korea concerning Joint Development of the Southern Part of the Continental Shelf Adjacent to the Two Countries. Sedangkan perjanjian atau persetujuan yang tidak secara tegas menggunakan istilah joint exploitation ataupun joint development, namun isi dan sama dengan perjanjian atau persetujuan yang menggunakannya secara tegas, misalnya Memorandum of Understanding between the Kingdom of Thailand and Malaysia on the Establishment of the Resources of the Seabed in a Defined Area of the Two Countries in the Gulf of Thailand.

27 Law of the Sea Bulletin No 23 June 1998, Division For Ocean Affair And The Law Of The Sea Office Of Legal Affairs, hlm. 67 
kepustakaan, ataupun praktek negara-negara, perjanjian semacam ini disebut joint exploitation agreement atau juga disebut joint development agreement. ${ }^{28}$

Melalui perjanjian ini, sumber daya alam yang menjadi obyek kerjasama di kawasan garis batas landas kontinen atau di kawasan landas kontinen yang tumpang tindih, secara hukum dijadikan sebagai satu kesatuan atau unity of deposit untuk selanjutnya dieksploitasi bersama sesuai dengan atau berdasarkan pada ketentuan-ketentuan perjanjian yang telah mereka sepakati. Secara umum, perjanjian semacam ini tidak terbatas hanya pada garis batas landas kontinen ataupun pada landas kontinen yang tumpang tindih saja, tetapi juga dapat dibuat dan diterapkan pada garis batas zona maritim lainnya seperti pada garis batas laut teritorial, dan garis batas zona ekonomi eksklusif. Bahkan juga dapat dibuat dan diterapkan untuk garis batas wilayah daratan. Masing-masing sesuai dengan obyek yang ada atau lintas batas pada garis batas dari zona maritim tersebut ataupun situasi dan kondisi setempat. ${ }^{29}$

Melalui perjanjian ini, maka masalah yang semula potensial sebagai sumber konflik, diubah dan diarahkan menjadi sumber kerjasama. Kerjasama tersebut pada umumnya meliputi eksplorasi, eksploitasi, dan pembagian keuntungan yang diperoleh dari eksploitasi sumber daya alam di kawasan tersebut bagi para pihak. Perjanjian tentang joint exploitation atau joint development sebagai kelanjutan.

Dalam hal ini, Konvensi Hukum Laut PBB 1982 menegaskan untuk negara-negara para pihak belum berhasil mencapai kesepakatan tentang garis batas landas kontinen mereka. Hal ini ditegaskan dalam Pasal 83 ayat 3 yang menyatakan:

Pending agreement as provided in paragraph 1, the States concerned, in a spirit of understanding and cooperation, shall make every effort to enter into provisional arrangements of a practical nature and, during this transitional period, not to jeopardized or hamper the reaching of the final agreement. Such arrangements shall be without prejudice to the final delimitation.

Perjanjian ini cukup dapat memenuhi keinginan dari negara-negara yang landas kontinennya berbatasan, khususnya dalam mengeksploitasi sumber daya alamnya yang lintas

28 Istilah joint exploitation ataupun joint development ini ada yang digunakan secara tegas dalam perjanjian yang bersangkutan, ada pula perjanjian yang tidak secara tegas menggunakannya. Perjanjian atau persetujuan yang menggunakan istilah joint exploitation, misalnya, Perjanjian antara Sudan dan Saudi Arabia yaitu Agreement between Sudan and Saudi Arabia relating to the Joint Exploration and Exploitation of the Natural Reseources of the Seabed and Subsoil of the Red Sea in a Defined Area of the Two Countries in the Red Sea, May. Persetujuan yang menggunakan istilah joint development, misalnya, Persetujuan antara Jepang dan Korea yaitu Agreement between Japan and the Republic of Korea concerning Joint Development of the Southern Part of the Continental Shelf Adjacent to the Two Countries. Sedangkan perjanjian atau persetujuan yang tidak secara tegas menggunakan istilah joint exploitation ataupun joint development, namun isi dan sama dengan perjanjian atau persetujuan yang menggunakannya secara tegas, misalnya Memorandum of Understanding between the Kingdom of Thailand and Malaysia on the Establishment of the Resources of the Seabed in a Defined Area of the Two Countries in the Gulf of Thailand.

29 James Harrison, Evolution of the law of the sea: developments in law-making in the wake of the 1982 Law of the Sea Convention, School of Law, University of Edinburgh., 2007, Hal 37 
batas. Hal ini terbukti dengan semakin banyaknya bermunculan perjanjian-perjanjian semacam ini. ${ }^{30}$

Dengan demikian, potensi konflik antara para pihak dapat diakomodasikan dan ditransformasikan menjadi suatu kerjasama. Hal ini jelas merupakan suatu langkah positif baik dalam hubungan bilateral antara kedua pihak, ataupun dalam kerangka meningkatkan kerjasama antara negara-negara se kawasan. ${ }^{31}$

Secara rinci UNCLOS 1982 menetapkan hak dan kewajiban, kedaulatan, hak-hak berdaulat dan yurisdiksi negara-negara dalam pemanfaatan dan pengelolaan laut.

Masalah lain yang perlu pemikiran dan tindakan nyata dari berlakunya UNCLOS 1982 adalah terkait dengan ketentuan Pasal 62 yang memberikan isyarat kewajiban negara pantai untuk memberikan kesempatan kepada negara-negara lain untuk mengekploitasi sumber daya hayati di perairan ZEE dalam hal negara pantai belum memanfaatkan peraiaran ZEEnya secara utuh. Ukuran kemampuan negara pantai untuk mengeksploitasi potensi perikanan di ZEE adalah tersedianya armada tangkap dengan penetapan Maximum Sustainable Yield (MSY) dan Total Allowable Catch (TAC). ${ }^{32}$

Ketentuan pada Pasal 83 ayat 3 Konvensi Hukum Laut PBB 1982 tidak ada dalam Konvensi tentang Landas Kontinen 1958. Akan tetapi dalam perjanjian atau persetujuan tentang joint exploitation atau joint development ini dapat diterima dalam praktek negaranegara. Hal ini terbukti dari perjanjian-perjanjian tentang garis batas landas kontinen di perbagai kawasan dunia ini yang diadakan pada masa antara tahun 1958 dan 1982 bahkan juga pada masa sesudahnya, banyak yang mencantumkan ketentuan yang isi dan jiwanya merupakan landasan bagi perjanjian-perjanjian tentang joint exploitation atau joint development. Beberapa diantaranya ada yang ditindaklanjuti dengan mengadakan joint exploitation atau joint development agreement. ${ }^{33}$ Demikian pula negara-negara yang gagal mencapai kesepakatan tentang garis batas landas kontinen menempuh alternatif dengan mengadakan perjanjian tentang joint exploitation atau joint development.

Di samping itu, adanya perjanjian tentang joint exploitation atau ini mempercepat proses pemanfaatan sumber daya alam dari kawasan tersebut demi kepentingan nasional para pihak. Perjanjian ini menuntaskan masalah yang masih ditinggalkan oleh perjanjian tentang garis batas landas kontinen sebagaimana diuraikan di atas.

30 Etty R. Agoes Perkembangan Konsep Joint Development dalam Pemanfaatan Kekayaan Alam di Laut; Oratio Dies yang disampaikan pada Dies Natalis Fakultas Hukum Universitas Katolik Parahyangan pada tanggal 13 September 1991 di Bandung.

31 Ibid

32 Ida Kurnia, "Pengaturan Sumber Daya Perikanan di Zona Ekonomi Eksklusif Indonesia", Mimbar Hukum Vol. 26 No. 2 Juni 2014, hlm. 206

33 Dengan berdirinya Timor Timur atau Timor Lorosae sebagai negara merdeka dan berdaulat, maka kelangsungan hidup dari Perjanjian tentang Celah Timor ini tergantung pada Timor Timur, apakah Timor Timur akan meneruskannya ataukah tidak. Pada lain pihak, Indonesia secara de facto ataupun de jure sudah tidak terkait lagi dengan Perjanjian tersebut. 


\section{Penutup}

Salah satu unsur keberhasilan pembangunan adalah mengelola sumber daya yang tersedia untuk dimanfaatkan seoptimal mungkin. Walaupun tersedia banyak sumber daya, apabila tidak mampu dikelola apalagi tidak dikelola dengan baik maka kemajuan negara yang bersangkutan akan terhambat. Pembagian hak sumber daya kelautan Indonesia dengan negara lain di wilayah perbatasan baru dapat dilakukan Indonesia jika penentuan batas-batas teritorial kelautan antar negara telah diselesaikan, iptek pengelolan sumber daya hayati laut telah teroptimalkan, serta kelembagaan manajemen kelautan telah terintegrasi dan terkoordinasi kuat.

\section{Daftar Pustaka}

Adiyanto, E., E. Eidman, L. Adrianto, "Tinjauan Hukum Dan Kebijakan Pengelolaan PulauPulau Kecil Terluar Indonesia (Studi Kasus Pulau Nipa)". Buletin Ekonomi Perikanan Volume, Vol. VII No. 2, Tahun 2007.

Astim Riyanto, Negara Kesatuan: Konsep dan Aktualisasinya, Yapemdo, Bandung, 2006,

Butcher, JG., Becoming and archipelagic state: the Djuanda Declaration of 1957 and the 'struggle' to gain international recognition of the archipelagic principle. Australian National University, ISEAS, Singapore, 2009.

Darsono, P., "Pemanfaatan Sumber Daya Laut dan Implikasinya Bagi Masyarakat Nelayan", Jurnal Oseana, Vol. XXIV No. 4, 1999.

Dirjen Strahan, Kajian Optimalisasi Penanganan Wilayah Perbatasan Maritim RI-RDTL Dalam Rangka Menjaga Keutuhan NKRI. Departemen Pertahanan RI., Jakarta, 2007,

Doug Bandow, The Law of the Sea Treaty Impeding American Entrepreneurship and Investment, Advancing Liberty From the Economy to Ecology, Competitive Enterprise Institute, 2007,

Etty R. Agoes, Perkembangan Konsep Joint Development dalam Pemanfaatan Kekayaan Alam di Laut; Oratio Dies yang disampaikan pada Dies Natalis Fakultas Hukum Universitas Katolik Parahyangan pada tanggal 13 September 1991 di Bandung.

Harry G Johnson, The New International Economic Order, Selected Papers No. 49 di unduh di https://www.chicagobooth.edu/ /media/0ABF9E91CCDB42C4BBA92737DCE91 EEA.pdf

Ida Kurnia, Pengaturan Sumber Daya Perikanan di Zona Ekonomi Eksklusif Indonesia, Mimbar Hukum Volume 26 No 2 Juni 2014.

I Made Andi Arsana, A Historical Survey of Indonesia's Maritime Boundary Agreements, Symposium on Maritime Boundaries in the Timor Sea: Perspectives in International Law Melbourne, 15 February 2016 di unduh di www.ugm.ac.id 
James Harrison, Evolution of the law of the sea: developments in law-making in the wake of the 1982 Law of the Sea Convention, School of Law, University of Edinburgh, 2007,

John Crawfurd, A Descriptive Dictionary of the Indian Islands and Adjacent Countries, Oxford University Press, Kuala Lumpur, 1971,

J. A. Draper, "The Indonesian Archipelagic State Doctrine and Law of the Sea: 'Territorial Grab or justifiable Necessity?”, International lawyer, vol. 11, 1977,

Law of the Sea Bulletin No 23 June 1998 Division For Ocean Affair And The Law Of The Sea Office Of Legal Affairs.

Prager, EJ and SA Earle, The Ocean, McGraw-Hill, Monteral,2000,

Marsetio, Aktualisasi Peran Pengawasan Wilayah Laut Dalam Mendukung Pembangunan Indonesia sebagai Negara Maritim Yang Tangguh. Makalah Laksamana TNI Dr. Marsetio, pada acara Kuliah Umum di hadapan Civitas Akademika Universitas Sumatera Utara di Medan, Januari 2015

Mubarak Djamali, OK Sumadiharga, 1998, Sumber Daya Rumput Laut dalam Potensi dan Penyebaran Sumber Daya Ikan Laut Di Perairan Indonesia, Komisi Nasional Pengkajian Stock Sumber Daya Ikan Laut Lembaga Ilmu Pengetahuan Indonesia. Dirjen Perikanan, LIPI, Puslitbangkan, Lapan, BPPT dan Fakultas Perikanan IPB.

Nybakken, J.W., Biologi Laut: Suatu Pendekatan Ekologi. (Penerjemah: M Eidmen, Koebiono, Dietrich, Hutomo, dan Sukardjo). PT Gramedia , Jakarta, 1986,

Sihotang, Japanton, Masalah Perbatasan Wilayah Laut Indonesia di Laut Arafura dan Laut Timor. LIPI Press, Jakarta, 2009, 